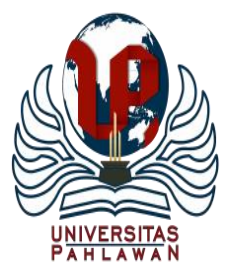

Edukatif : Jurnal Ilmu Pendidikan Volume 3 Nomor 5 Tahun 2021 Halm 2114 - 2122

EDUKATIF: JURNAL ILMU PENDIDIKAN

Research \& Learning in Education

https://edukatif.org/index.php/edukatif/index

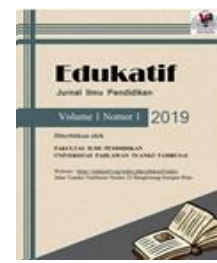

\title{
Lingkungan Keluarga dan Motivasi Belajar terhadap Hasil Belajar Mata Pelajaran Ekonomi pada Pembelajaran Daring
}

\author{
Affan Rais Annauval ${ }^{1 凶}$, Muhammad Abdul Ghofur ${ }^{2}$ \\ Universitas Negeri Surabaya, Indonesia ${ }^{1,2}$ \\ E-mail : affanrais2@gmail.com ${ }^{1}, \underline{\text { muhammadghofur@unesa.ac.id }}^{2}$
}

\begin{abstract}
Abstrak
Keluarga dan motivasi belajar merupakan faktor penting yang sangat berpengaruh pada kinerja akademik siswa, khususnya pada pembelajaran dimasa pandemi Covid-19. Atas dasar masalah tersebut penelitian ini akan lebih fokus pada lingkungan keluarga dan motivasi belajar pada hasil belajar ekonomi pada pembelajaran daring. Penelitian ini bertujuan untuk mengetahui secara parsial maupun simultan Pengaruh Lingkungan Keluarga dan Motivasi Belajar terhadap Hasil Belajar Mata Pelajaran Ekonomi pada Pembelajaran Daring. Populasi penelitian ini adalah siswa kelas XI IPS MAN 2 NGANJUK yang berjumlah 106 siswa. Metode pengumpulan data menggunakan data primer dan data sekunder, yaitu angket dan dokumentasi nilai UAS. Dalam penelitian ini analisis regresi linier berganda digunakan untuk menganalisis data yang diperoleh. Hasil penelitian menunjukkan bahwa 1) Lingkungan keluarga tidak mempunyai pengaruh signifikan. 2) Hasil belajar dipengaruhi oleh motivasi belajar secara positif dan signifikan .3) Hasil belajar ekonomi dipengaruhi oleh lingkungan keluarga dan motivasi belajar secara bersama-sama.
\end{abstract}

Kata Kunci: Pembelajaran Daring, Hasil Belajar, Motivasi Belajar, Lingkungan Keluarga.

\begin{abstract}
Family and learning motivation are important factors that greatly influence students' academic performance, especially in learning during the Covid-19 pandemic. Based on these problems, this research will focus more on the family environment and learning motivation on economic learning outcomes in online learning. This study aims to determine partially or simultaneously the influence of family environment and learning motivation on learning outcomes of economic subjects in online learning. The population of this study were students of class XI IPS MAN 2 NGANJUK, totaling 106 students. The data collection method used primary data and secondary data, namely questionnaires and documentation of UAS scores. In this study, multiple linear regression analysis was used to analyze the data obtained. The results showed that 1) Family environment had no significant effect. 2) Learning outcomes were positively and significantly influenced by learning motivation. 3) Economics learning outcomes were influenced by family environment and learning motivation together.
\end{abstract}

Keywords: Online Learning, Learning Outcomes, Learning Motivation, Family Environment.

Copyright (c) 2021 Affan Rais Annauval, Muhammad Abdul Ghofur

$\triangle$ Corresponding author

Email : affanrais2@gmail.com

DOI $\quad$ : https://doi.org/10.31004/edukatif.v3i5.761

ISSN 2656-8063 (Media Cetak)

ISSN 2656-8071 (Media Online)

Edukatif : Jurnal Ilmu Pendidikan Vol 3 No 5 Tahun 2021 p-ISSN 2656-8063 e-ISSN 2656-8071 
2115 Lingkungan Keluarga dan Motivasi Belajar terhadap Hasil Belajar Mata Pelajaran Ekonomi pada Pembelajaran Daring - Affan Rais Annauval, Muhammad Abdul Ghofur

DOI: https://doi.org/10.31004/edukatif.v3i5.761

\section{PENDAHULUAN}

Perkembangan zaman yang melaju pesat manusia dituntut untuk memperoleh kualitas pendidikan yang baik, hal ini secara tidak langsung berkaitan dengan meningkatnya hasil belajar yang dilakukan oleh siswa (Seftannency, Parijo, \& Utomo, 2014). Dewasa ini, masih banyak sekali permasalahan di dalam dunia pendidikan yang dapat menghalangi tercapainya tujuan-tujuan yang diharapkan. Saat ini dunia sedang dilanda pandemi yang berdampak kepada berbagai termasuk sektor pendidikan. Supaya terhindar dan dapat mengurangi peneyebaran virus Corona yang dilanda dunia saat ini pemerintah telah mengeluarkan kebijakan baru. Kebijakan baru ini biasa disebut dengan social distancing. Namun dengan adanya kebijakan tersebut setiap masyarakat yang melakukan aktivitas mengumpulkan orang banyak terpaksa harus dihentikan dan menggantinya dengan aktivitas di dalam rumah. Dalam masa darurat pandemi SE Nomor 4 Tahun 2020 tentang Pelaksanaan Kebijakan Pendidikan dikeluarkan pemerintah melalui Kemendikbud. Berdasarkan surat edaran tersebut seluruh lembaga pendidikan diwajibkan menggunakan metode pembelajaran yang berbeda saat pandemi ini yaitu pembelajaran online atau dalam jaringan (daring). Hal ini mengakibatkan siswa dan guru tidak melakukan pembelajaran secara tatap muka atau secara langsung. Pembelajaran dalam jaringan merupakan satu dari beberapa metode pembelajaran yang dimana terdapat aktivitas pembelajaran yang dilaksanakan secara terpisah dari aktivitas belajar (Mustofa ,2019). Dalam kedaan ini pasti akan berdampak pada kualitas pembelajaran yang biasanya siswa dan guru melakukan interaksi langsung sekarang harus melakukan interaksi dalam ruang virtual yang terbatas (Cahyani, Listiana, \& Larasati, 2020).

Kognitif, afektif, dan psikomotorik menjadi ranah untuk mencakup sebuah hasil pembelajaran. Guru sering melihat ranah kognitif siswa untuk menilai kemampuan siswa dalam menguasai materi (Sudjana, 2017). Berdasarkan data MAN 2 NGANJUK bahwa hasil belajar ekonomi siswa masih dibawah rata-rata ketika pembelajaran daring saat pandemi. Hasil belajar mapel ekonomi siswa masih di bawah standar nilai KKM. Dari hasil ulangan akhir semester hanya terdapat 10\% dari 106 siswa kelas XI yang nilai ulangan akhir semesternya memenuhi KKM ,yaitu 75. Hal tersebut menunjukkan bahwa keberhasilan tujuan pembelajaran daring pada masa pandemi covid-19 ini belum tercapai seutuhnya. Salah satu penyebab sebab hasil belajar peserta didik belum maksimal karena adanya hal yang kurang mendukung dalam lingkungan keluarga.

Slameto (2010) mengemukakan keluarga menjadi salah saru faktor yang mempengaruhi hasil belajar. Pendidikan pertama yang diperoleh siswa berada pada sebuah keluarga (Wahid, Setiyoko, Riono, \& Saputra, 2020). Keberhasilan belajar seorang anak dipegang oleh sebuah keluarga terlebih lagi para orang tua. Sikap kepedulian orang tua kepada anak akan memberikan pembentukkan pola berfikir dan prestasi yang baik (Handayani, 2017). Hal ini sejalan dengan pendapat Slameto (2010: 60) bahwa belajar seorang anak akan dipengaruhi oleh bagaimana orang tua mendidik. Ketika pembelajaran dirumah tingkat keinginan anak untuk terus belajar, sikap mandiri peserta didik dan dukungan keluarga sangat berpengaruh pada keberhasilan balajar di rumah (Sari, 2020). Kondisi Lingkungan keluarga seorang anak akan sangat menentukan tingkat pencapaian hasil belajar. Ini sama dengan penelitian (Utaminingtyas, Subaryana, \& Fatimah, 2020), bahwa sebuah hasil beajar akan dipengaruhi oleh lingkungan keluarga. Hal ini menunjukkan hasil belajar siswa dapat ditentukan oleh Lingkungan Keluarga. Namun kenyataanya berdasarkan wawancara kepada siswa di MAN 2 Nganjuk orang tua mereka cenderung hanya sekedar mengetahui bahwa anak mereka sedang melakukan pembelajaran daring sesuai jadwal dari sekolah. Tetapi tidak mengawasi mereka sepenuhnya, entah mereka tertidur, mengerjakan tugas dari guru atau tidak, maupun tidak mengikuti pembelajaran daring. Kemudian keadaan ekonomi juga memaksa orang tua bekerja, sehingga harus membagi waktu antara bekerja atau memberikan perhatian pada anak.

Grand theory yang digunakan untuk mendasari variabel-variabel yang digunakan yaitu teori behavioristik dan teori harapan (expectancy theory). Teori behavioristik yang dikembangkan oleh aliran behavioristik memiliki pandangan bahwa belajar adalah hasil perubahan tingkah laku yang kemampuan 
internal manusia tidak menyebabkan hal itu, tetapi karena adanya sebuah respon yang ditimbulkan stimulus (Rifai \& Anni, 2012). Sedangkan dari pandangan lain, Dalyono (2012:30) menggambarkan aktivitas siswa dapat dipengaruhi oleh reward atau reinforcement dari sekitar lingkungan. Selain teori behavioristik penelitian ini menggunakan teori harapan. Dalam teori yang kedua yaitu teori harapan, teori ini menempatkan motivasi sebagai dampak untuk mencapai suatu hasil serta gambaran dari pikiran seseorang bahwa tindakannya tersebut akan membuahkan hasil yang dia inginkan (Siagian, 2004). Pandangan lain dari Danim (2012) menyatakan bahwa harapan merupakan kepercayaan dari usaha yang dilakukan akan menimbulkan sesuatu yang di inginkan.

Selain faktor lingkungan keluarga terdapat unsur lain yang memengaruhi hasil belajar siswa yaitu motivasi. Motivasi sendiri yaitu sesuatu dorogan yang dimiliki setiap manusia untuk melakukan sesuatu (Uno, 2014). Hal ini sama dengan keinginan belajar pada siswa, dengan adanya dorongan diharapkan prestasi yang di inginkan bisa tercapai. Sardiman (2012:74) berpendapat, agar arah dan tujuan yang dikehendak dalam belajar dapat tercapai manusia harus memiliki sebuah dorongan yaitu motivasi belajar. Pada pembelajaran daring harus dituntut untuk lebih termotivasi sebab lingkungan belajar ini bergantung pada karakteristik dan motivasi dari rasa ingin tau dan pengaturan diri untuk terlibat dalam proses pembelajaran (Selvi, 2010). Oleh karena itu memiliki motivasi belajar sangat penting bagi setiap siswa untuk menentukan tingkat pencapaian hasil belajarnya. Kenyataanya Kondisi saat pembelajaran daring masa pandemi Covid-19 ini siswa juga mengalami penurunan motivasi dalam belajar. Hal tersebut bisa dilihat dari keaktifan siswa saat pembelajaran daring, ada beberapa siswa tidak mengikuti pembelajaran daring sepenuhnya. Banyak pula peserta didik tidak mengumpulkan tugas pada batas waktu yang telah diberikan. Motivasi belajar yang rendah dapat berakibat pada hasil belajar nantinya. Hal ini sama dengan penelitian (Sunadi, 2010) bahwa hasil belajar dipengaruhi oleh motivasi.

Menurut hasil penelitian (Novianti, Sadipun, \& Balan, 2020) tentang "Pengaruh Motivasi Belajar terhadap Hasil Belajar Matematika Peserta Didik" mengungkapkan bahwa motivasi berpengaruh kuat dengan hasil belajar Matematika dengan presentase 34,3\%. Selain itu penelitian oleh (Fane \& Sugito, 2019) yang juga meneliti variabel motivasi dengan subjek berbeda yakni SMA Negeri 4 Yogyakarta mendapatakan hasil yang sama. Perbedaan pada penelitian ini dengan penelitian terdahulu yakni pada subjek dan fenomena penelitian berbeda serta di MAN 2 Nganjuk belum pernah dilakukan penelitian dengan tema sejenis. Dengan adanya kebijakan mengenai pembelajaran daring saat pandemi covid 19 ini, yang akan dilaksanakan sampai waktu yang belum ditentukan maka dari itu perlu dilakukannya penelitian mengenai faktor yang diduga dapat mempengaruhi hasil belajar mata pelajaran ekonomi siswa. Tingkat keberhasilan pendidikan dilihat dari perolehan hasil belajar siswa, maka penelitian tentang lingkungan keluarga dan motivasi belajar perlu dilakukan untuk mengetahui apakah dapat mempengaruhi hasil belajar yang diperoleh terutama pada pembelajaran daring dimasa Covid-9.

Berlandaskan dari uraian diatas maka dilakukan penelitian dengan judul "Lingkungan Keluarga dan Motivasi Belajar terhadap Hasil Belajar Mata Pelajaran Ekonomi” ini bertujuan untuk menganalisis bagaiana Pengaruh Lingkungan Keluarga dan Motivasi Belajar secara parsial maupun simultan terhadap hasil belajar mata pelajaran ekonomi siswa kelas XI IPS MAN 2 Nganjuk. Hasil penelitian ini diharapkan dapat digunakan sebagai bahan pertimbangan guru maupun lembaga pendidikan untuk meningkatkan hasil belajar siswa pada pembelajaran daring di masa pandemi covid-19.

\section{METODE PENELITIAN}

Penelitian ini digolongkan sebagai sebuah penelitian kuantitatif dengan metode korelasi. Dalam hal ini menggambarkan hubungan Lingkungan Keluarga (X1) dan Motivasi belajar (X2) dengan Hasil Belajar (Y). Penulis mengambil populasi yang berasal dari siswa kelas XI IPS yang berada di MAN 2 Nganjuk dengan 
jumlah 106 siswa. Penelitian ini menggunakan data primer yang berasal dari hasil jawaban kuesioner yang disebarkan kepada responden melalui google form, yang meliputi kuesioner motivasi belajar dan lingkungan keluarga. Sedangkan data sekunder diperoleh penulis dari nilai Ulangan Akhir Semester (UAS).

Kuisioner telah melalui uji validitas dan reliabilitas kepada 21 siswa sebelum disebarkan kepada para responden subjek yang akan diteliti. Valid tidaknya suatu instrumen dalam penelitian ini dilihat berdasarkan nilai person product moment pada hasil pengujian, sedangkan reliable atau tidaknya suatu instrumen dari penelitian ini dihitung berdasarkan nilai Cronbach Alpha berdasarkan data hasil pengujian. Penulis menggunakan metode analisis linier berganda untuk melaksanakan proses analisis, proses analisis data sendiri dilaksanakan dengan program IBM SPSS Statistics 25. Untuk proses analisis data yang dilaksanakan yaitu uji asumsi klasik, dan uji hipotesis.

\section{HASIL DAN PEMBAHASAN PENELITIAN}

Uji statistik one sample Kolmogrov-Smirnof Test merupakan uji normalitas yang dilakukan pada riset ini, dimana ketika signifikansi > 5\% (Asymp.Sg > 0,05) maka uji normalitas tercapai. Hasil nilai Asmp.Sig sebesar 0,175>0,05 yang didasarkan pada perolehan uji normalitas maka residual dapat dikatakan telah terdistribusi secara normal. Pada uji linieritas ditunjukkan bahwa nilai Sig. pada Deviation from Linearity, variabel dependen serta independen yaitu (X1) 0,432>0,05 dan (X2) 0,834 > 0,05, dari perolehan tersebut diasumsikan linieritas telah terpenuhi yaitu variabel independen dan dependen terjadi hubungan yang linier. Didasari dari hasil uji multikolinieritas ditunjukkan bahwa besarnya nilai tolerance pada tiap yaitu variabel X2 dan X1 $0,933 \geq 0,10$, selanjutnya nilai VIF pada tiap variabel yaitu variabel X1 dan X2 1,084 $\leq 10$, maka dapat ditarik kesimpulan bahwa tidak ditemui adanya korelasi signifikan tiap variabel bebas dalam model regresi. Metode uji Glejser diunakan untuk uji heterokedastisitas, ditunjukkan bahwa besarnya signifikansi pada variabel independen sebanyak X1 0,128>0,05, dan variabel X2 0,858>0,05 hal ini berarti dinyatakan bahwa dalam permodelan residual tidak heteroskedastisitas (homokedastisitas).

Perolehan Uji Analaisis Regresi Berganda

Tabel.1

\begin{tabular}{lccc}
\hline \multicolumn{1}{c}{ Variabel } & $\begin{array}{c}\text { Koefisien } \\
\text { Regresi }\end{array}$ & T hitung & Sig. \\
\hline Konstanta & 13,729 &, 070 & \\
X1 & & 1,074 &, 830 \\
X2 & & &, 000 \\
\hline F hitung $=10,115$ & & & 000
\end{tabular}

Adj.R2 $=0,148$

$$
\mathrm{Y}=13,729+0,070(\mathrm{X} 1)+1,074(\mathrm{X} 2)
$$

Didasari dari Tabel.1 setiap variabel X1 terjadi peningkatan sebesar satu poin, kemudian pada variabel X2 ialah tetap, maka dapat menyebabkan peningkatan hasil belajar sebesar 0,70. Setiap variabel X2 terjadi peningkatan sebesar satu poin, kemudian pada variabel X1 ialah tetap, maka dapat menyebabkan peningkatan hasil belajar sebesar 1,074. Didasarkan pada Uji t pada Tabel.1 variabel (X1) memiliki nilai signifikasi (Sig.) dan thitung sebesar 0,830 > 0,05 dan 0,216 < ttabel (1,983), akhirnya ditarik kesimpulan bahwa Ho diterima dan Ha1 ditolak,bahwa tidak memiliki pengaruh secara parsial antara (X1) terhadap (Y). Variabel Motivasi 

Pembelajaran Daring - Affan Rais Annauval, Muhammad Abdul Ghofur

DOI: https://doi.org/10.31004/edukatif.v3i5.761

Belajar (X2) memiliki nilai signifikans (Sig.) dan t hitung sebesar 0,000 $<0,05$ dan 4,254 > ttabel $(1,983)$, hasil ini dapat ditarik kesimpulan bahwa Ho ditolak dan Ha2 diterima dalam artian secara parsial antara variabel (X2) terhadap Hasil Belajar saling mempengaruhi. Mengetahui nilai signifikansi (Sig.) dari Uji $\mathrm{F}$ untuk pengaruh variabel $(\mathrm{X} 1)$ dan $(\mathrm{X} 2)$ secara simultan variabel $(\mathrm{Y})$ adalah sebesar $0,000<0,05$ dan nilai Fhitung 13,035 > Ftabel 3,08. akhirnya, dapat ditarik kesimpulan bahwa Ho ditolak dan Ha3 diterima dapat diartikan variabel X1 dan X2 secara simultan berakibat secara positif serta signifikan kepada variabel Y. Pada analisis $\left(\mathrm{r}^{2}\right)$ mendapatkan nilai sebesar 0,148 , artinya kontribusi (X1) dan (X2) terhadap (Y) sebesar 0,148 atau $14,8 \%$ dan sebesar $85,2 \%$ tidak membahas variabel lain .

\section{Lingkungan Keluarga terhadap Hasil Belajar Mata Pelajaran Ekonomi pada Pembelajaran Daring}

Setelah penulis melaksanakan penelitian, diperoleh hasil bahwa tidak terdapat adanya pengaruh yang ditimbulkan dari lingkungan keluarga terhadap hasil belajar ekonomi pada siswa kelas XI IPS di MAN 2 Nganjuk. Hal ini bertentangan dengan teori Slameto yang mengungkapkan bahwa keluarga mempengaruhi hasil belajar. Hal ini ditunjukkan siswa yang memiliki nilai dibawah KKM terdapat berada pada lingkungan keluarga yang baik,begitu juga sebaliknya. Meskipun variabel Lingkungan keluarga terbilang baik yaitu 73\% tapi hanya sekitar $10 \%$ dari siswa yang memiliki nilai diatas KKM yang telah ditentukan. Hal tersebut berdasarkan data hasil belajar dan data primer yang didapat untuk variabel lingkungan keluarga. hal ini menunnjukkan hubungan lingkungan keluarga masih belum cukup untuk mempengaruhi siswa pada pembelajaran dari di era covid-19 ini secara maksimal.

Dalyono (2012) menggambarkan tingkah laku belajar siswa dikendalikan oleh (reward) atau (reinforcement) dari lingkungan. Hasbullah (2012) menerangkan bahwa sekolah, keluarga dan lingkungan memliki tanggung jawab secara bersama-sama kepada pendidikan. Kualitas lingkungan keluarga yang tinggi, dapat berpotensi dalam meningkatkan hasil belajarnya sang siswa, begitu juga sebaliknya. Tetapi dalam penelitian ini sangat bertentangan dengan teori bahwa lingkungan keluarga mempengaruhi hasil belajar. Ada kemungkinan bahwa ada faktor lain yang lebih besar dalam hal ganjaran (reward) atau penguatan (reinforcement) dibandingkan lingkungan keluarga yang dapat mempengaruhi hasil belajar siswa pada pembelajaran daring. Dengan kondisi pandemi mengharuskan interaksi antara siswa dengan guru menjadi terbatas. Hal tersebut yang membuat peserta didik harus mampu mengatur kegiatan pembelajaran agar hasil yang maksimal tanpa bantuan Keluarga.

Lingkungan keluarga yang baik belum tentu dapat mempengaruhi hasil pembelajaran ekonomi siswa, begitu juga sebaliknya pada pembelajaran daring era pandemi ini. Hal ini berarti siswa sudah bisa mandiri dan tidak bergantung pada keluarga lagi, meskipun ada beberapa siswa yang masih bergantung. Berlandaskan penelitian yang penulis laksanakan, dikatakan bahwa pencapaian hasil belajar mata pelajaran ekonomi siswa pada penelitian ini tidak didukung oleh lingkungan keluarga. Dalam hal ini penelitian yang telah dilakukan pada variabel lingkungan keluarga tidak berpengaruh pada hasil belajar mata pelajaran ekonomi pada pembelajaran daring siswa kelas XI IPS MAN 2 Nganjuk. Hal ini sesuai dengan penelitian (Wahyuni, 2016) yang memperoleh kesimpulan bahwa Persepsi siswa tentang komunikasi orang tua memberikan pengaruh negatif secara langsung dan tidak signifikan kepada hasil belajar .Penelitian ini sesuai dengan penelitian (Pujiningrum \& Siswanto, 2021) bahwa perhatian orang tua pada pembelajaran daring tidak berpengaruh signifikan pada hasil belajar siswa. Berdasarkan uraian hasil penelitian peserta didik yang memiliki kondisi lingkungan keluarga yang baik ,belum tentu memiliki hasil belajar yang baik pula. Maka dapat diartikan bahwa pada kelas XI IPS MAN 2 Nganjuk Kondisi Lingkungan Keluarga tidak berpengaruh pada hasil belajar ekonomi peserta didik. 
2119 Lingkungan Keluarga dan Motivasi Belajar terhadap Hasil Belajar Mata Pelajaran Ekonomi pada Pembelajaran Daring - Affan Rais Annauval, Muhammad Abdul Ghofur

DOI: https://doi.org/10.31004/edukatif.v3i5.761

\section{Motivasi Belajar terhadap Hasil Belajar Mata Pelajaran Ekonomi pada Pembelajaran Daring}

Setelah penulis melaksanakan penelitian, diperoleh hasil bahwa secara parsial hasil belajar mata pelajaran Ekonomi siswa kelas IX IPS di MAN 2 Nganjuk dipengaruhi oleh motivasi belajar. Kesimpulan ini berangkat dari hasil olah data pada Tabel 1 yang menunjukkan bahwa nilai signifikansi variabel Motivasi Belajar $(X 2)(0,000)<0,05$ terhadap variabel Hasil Belajar. Sehingga, diperoleh kesimpulan bahwa Hipotesis dua diterima, dalam artian Variabel X1 memberikan pengaruh yang signifikan dan positif pada variabel Y.

Hasil penelitian ini sesuai dengan (Rahmawati, 2016) bahwa salah satu faktor yang mempengaruhi hasil belajar yaitu Motivasi. Emda (2018) mengatakan bahwa untuk memperoleh keberhasilan dalam sebuah proses pembelajaran, seorang siswa harus mempunyai motivasi yang tinggi dalam menjalani kegiatan pembelajaran. Kondisi pandemi yang menyulitkan banyak pihak mengaharuskan sistem pembelajaran daring yang membuat siswa kesulitan untuk berinteraksi dengan teman maupun gurunya. Pada permasalahan tersebut siswa harus mampu mengatur dirinya secara mandiri agar tetap semangat dan tidak putus asa. dengan adanya motivasi yang menjadi dorongan dasar yang membuat manusia bergerak untuk bertingkah laku sebuah dorongan tersebut. Menurut (Hamzah, 2013) asal dari dorongan tersebut yatu dari faktor luar maupun dalam seorang peserta didik yang sedang merubah tingkah laku, dan didukung oleh berbagai macam unsur. Seorang siswa berpotensi mendapatkan hasil belajar yang tinggi jika mereka memiliki motivasi yang tinggi dalam menjalani proses pembelajaran. Siswa yang merasa ada kemungkinan yang tinggi untuk memperbaiki prestasi belajarnya dengan mengembangkan usahanya sendiri, maka siswa tersebut mempunyai tingkat pengharapan yang tinggi.

Hasil temuan ini berarti membuat motivasi menjadi sangat penting dimiliki tiap peserta didik terlebih lagi pada pembelajaran dari di era covid-19 ini. Siswa yang memiliki keinginan untuk maju pasti akan mendapatkan hasil belajar yang di inginkan. Hal ini juga didukung oleh penelitian (Putri Ningrat, Tegeh, \& Sumantri, 2018) dan (Sutardi \& Sugiharsono, 2016) bahwa motivasi belajar memengaruhi hasil belajar siswa.

\section{Motivasi Belajar dan Lingkungan Keluarga terhadap Hasil Belajar Mata Pelajaran Ekonomi pada Pembelajaran Daring}

Berlandaskan hasil analisis regresi yang telah penulis lakukan, diperoleh hasil bahwa (X1) dan (X2) secara bersama-sama memberikan pengaruh positif dan signifikan terhadap (Y). Kesimpulan ini berangkat dari hasil pada Tabel.1, pada uji F diketahui memiliki nilai signifikansi (Sig.) Variabel X1 dan X2 terhadap variabel $(Y)$ secara simultan adalah sebesar $0,000<0,05$ serta nilai Fhitung $(10,155)>$ Ftabel $(3,08)$. Sehingga, dapat ditarik kesimpulan bahwa hipotesis ketiga diterima, artinya variabel X1 dan X2 bersamasama berpengaruh secara positif dan signifikan terhadap variabel hasil belajar. Diketahui dari $\mathrm{R}^{2}$ bahwa pengaruh (X1) dan (X2) pada hasil belajar terbilang kecil, karena ada pengaruh yang lebih besar yang tidak diteliti pada peneitian ini.

Motivasi belajar sangat dibutuhkan peserta didik, tanpa motivasi belajar siswa hanya akan menerima perintah dari guru tanpa bisa meningkatkan kreativitas dan kemandiriannya dalam belajar. Mengingat hasil penelitian (Sahita \& Rachmawati, 2018) yakni motivasi belajar menjadi unsur yang mempengaruhi hasil belajar. Pada penelitian tersebut menunjukkan bahwa tingkat motivasi berbanding lurus dengan hasil belajar yang berpengaruh positif signifikan.

Begitu juga dengan lingkungan keluarga,relasi antar keluarga baik, perhatian orang tua yang membuat anak nyaman, serta kebutuhan anak terpenuhi maka hasil belajar pun akan meningkat. Terlebih lagi saat pembelajaran daring pada era covid-19 ini. Siswa harus mendapat ketenangan dan perhatian lebih dari keluarga karena keluarga yang sering bertemu dengan siswa. Penelitian ini didukung oleh (Rahayu, 2016) yang mengatakan terdapat pengaruh positif signifikan antara lingkungan keluarga dengan hasil belajar sosiologi.

Hal ini berarti semakin baik lingkungan keluarga dan semakin tinggi motivasi belajar maka hasil belajar akan meningkat. Hasil penelitian ini sesuai dengan pendapat Dalyono (2012) yang mengemukakan faktor 

Pembelajaran Daring - Affan Rais Annauval, Muhammad Abdul Ghofur

DOI: https://doi.org/10.31004/edukatif.v3i5.761

penentu pencapaian hasil belajar yaitu meliputi keluarga dan motivasi. Jika dalam sebuah keluarga dapat menciptakan suasana belajar yang menenangkan maka hal ini tentu saja akan mempengaruhi hasil belajar dari seorang peserta didik. Tentu saja hal tersebut harus didukung oleh motivasi belajar yang tinggi pula. Supaya tercapainya keberhasilan dalam pembelajaran daring harus didampingi dengan lingkungan keluarga dan motivasi secara bersamaaan. Adanya perubahan pada metode pembelajaran yang dilakukan saat kondisi pandemi ini membuat siswa harus mandiri. Siswa tidak boleh bergantung pada keluarga pada saat kondisi pembelajaran daring, siswa harus memiliki motivasi yang kuat supaya bisa mencapai keberhasilan dalam belajar.

Hasil dari penelitian ini didukung oleh (Jamil \& Azra, 2014),(Purbuyanto \& Rustiana, 2018). dan (Chulsum, 2017) bahwa hasil belajar dipengaruhi oleh lingkungan keluarga dan motivasi belajar. Keterbatasan penelitian ini ialah pada variabel yang diteliti hanya meneliti mengenai dua faktormempengaruhi hasil belajar yakni Lingkungan Keluarga dan Motivasi Belajar. Pada penelitian ini hasil belajarpeserta didik dikhususkan untuk mata pelajaran ekonomi pada kelas XI IPS MAN 2 Nganjuk Tahun Ajaran 2020/2021. Penelitian dilaksanakan secara daring karena sebagai dampak dari kondisi sistem pembelajaran dimasa pandemi Covid19.

\section{KESIMPULAN}

Hasil penelitian ini dapat disimpulkan bahwa hasil belajar tidak dipengaruhi oleh lingkungan keluarga, motivasi belajar yang tinggi dapat mempengaruhi hasil belajar, serta secara simultan motivasi belajar dan lingkungan keluarga dapat mempengaruhi hasil belajar mata pelajaran ekonomi pada pembelajaran daring siswa kelas XI IPS di MAN 2 Nganjuk. Seorang siswa yang motivasi belajarnya tinggi akan berpotensi mendapatkan hasil belajar yang baik. Jadi disarankan dalam pembelajaran daring peserta didik harus ditingkatkan dalam motivasi belajarnya dan keluarga harus mendukung peserta didik dalam melakukan belajar pada masa pandemi covid-19 ini.

\section{DAFTAR PUSTAKA}

Cahyani, A., Listiana, I. D., \& Larasati, S. P. D. (2020). Motivasi Belajar Siswa Sma Pada Pembelajaran Daring Di Masa Pandemi Covid-19. Iq (Ilmu Al-Qur'an): Jurnal Pendidikan Islam, 3(01), 123-140. Https://Doi.Org/10.37542/Iq.V3i01.57

Chulsum, U. (2017). Pengaruh Lingkungan Keluarga, Kedisiplinan Siswa, Dan Motivasi Belajar Terhadap Hasil Belajar Ekonomi Siswa Di Sma Negeri 7 Surabaya. Jurnal Ekonomi Pendidikan Dan Kewirausahaan, Vol. 5, P. 5. Https://Doi.Org/10.26740/Jepk.V5n1.P5-20

Dalyono. (2012). Psikologi Pendidikan. Rineka Cipta.

Danim, S. (2012). Kepemimpinan Pendidikan: Kepemimpinan Jenius $(I q+E q)$, Etika, Perilaku Motivasional, Dan Mitos. Bandung: Alfabeta.

Emda, A. (2018). Kedudukan Motivasi Belajar Siswa Dalam Pembelajaran. Lantanida Journal, 5(2), 172. Https://Doi.Org/10.22373/Lj.V5i2.2838

Fane, A., \& Sugito, S. (2019). Pengaruh Keterlibatan Orang Tua, Perilaku Guru, Dan Motivasi Belajar Terhadap Prestasi Belajar Matematika Siswa. Jurnal Riset Pendidikan Matematika, 6(1), 53-61. Https://Doi.Org/10.21831/Jrpm.V6i1.15246

Hamzah, B. U. (2013). Teori Motivasi Dan Pengukurannya. Jakarta: Bumi Aksara.

Handayani, D. (2017). Pengaruh Perhatian Orang Tua Dan Konsep Diri Siswa Terhadap Hasil Belajar Matematika Siswa. Jurnal Pendidikan Dasar, 8(1), 127-143. 
2121 Lingkungan Keluarga dan Motivasi Belajar terhadap Hasil Belajar Mata Pelajaran Ekonomi pada Pembelajaran Daring - Affan Rais Annauval, Muhammad Abdul Ghofur

DOI: https://doi.org/10.31004/edukatif.v3i5.761

Jamil, H., \& Azra, F. I. (2014). Pengaruh Lingkungan Keluarga Dan Motivasi Belajar Siswa Terhadap Hasil Belajar Akuntansi Siswa Kelas X Smk Negeri 1 Solok Selatan. Journal Of Economic And Economic Education, 2(2), 85-98.

Mustofa, M. I., Chodzirin, M., Sayekti, L., \& Fauzan, R. (2019). Formulasi Model Perkuliahan Daring Sebagai Upaya Menekan Disparitas Kualitas Perguruan Tinggi. Walisongo Journal Of Information Technology, 1(2), 151. Https://Doi.Org/10.21580/Wjit.2019.1.2.4067

Novianti, C., Sadipun, B., \& Balan, J. M. (2020). Pengaruh Motivasi Belajar Terhadap Hasil Belajar Matematika Peserta Didik. Science And Phich Education Jurnal, 3(2).

Pujiningrum, E., \& Siswanto, J. (2021). Pengaruh Perhatian Orang Tua Dan Minat Belajar Siswa Pada Pembelajaran Daring Terhadap Hasil Belajar Matematika Kelas V Sd Negeri Mangunrekso 01. 2(1), 111.

Purbuyanto, R., \& Rustiana, A. (2018). Pengaruh Disiplin Belajar, Lingkungan Keluarga, Dan Motivasi Belajar Terhadap Hasil Belajar Siswa. Economic Education Analysis Journal, 7(1), 341-361.

Putri Ningrat, S., Tegeh, I. M., \& Sumantri, M. (2018). Kontribusi Gaya Belajar Dan Motivasi Belajar Terhadap Hasil Belajar Bahasa Indonesia. Jurnal Ilmiah Sekolah Dasar, 2(3), 257. Https://Doi.Org/10.23887/Jisd.V2i3.16140

Rahayu, S. (2016). Hubungan Lingkungan Keluarga Terhadap Hasil Belajar Sosiologi Di Sma Negeri 16 Padang. Jurnal Ilmu Sosial Mamangan, 5.1, 50-59.

Rahmawati, R. (2016). Motivasi Belajar, Fasilitas Belajar, Lingkungan Keluarga Dan Faktor-Faktor Lain. Jurnal Pendidikan Dan Ekonomi, 5(4), 326-336.

Rifai, A., \& Anni, C. T. (2012). Psikologi Pendidikan. Upt Unnes Press.

Sahita, N. A., \& Rachmawati, L. (2018). Pengaruh Motivasi Dan Fasilitas Belajar Di Rumah Terhadap Hasil Belajar Ekonomi Kelas X Iis Sma Hang Tuah 1 Surabaya. Jpeka: Jurnal Pendidikan Ekonomi, Manajemen Dan Keuangan, Vol. 2, P. 97. Https://Doi.Org/10.26740/Jpeka.V2n2.P97-106

Sardiman, A. M. (2012). Interaksi Dan Motivasi Belajar Mengajar. Jakarta: Bumi Aksara.

Sari, T. T. (2020). Self-Efficacy Dan Dukungan Keluarga Dalam Keberhasilan Belajar Dari Rumah Di Masa Pandemi Covid-19. Education Journal: Journal Educational Research And Development, 4(2), 127 136. Https://Doi.Org/10.31537/Ej.V4i2.346

Seftannency, I., Parijo, \& Utomo, B. B. (2014). Pengaruh Lingkungan Keluarga Terhadap Hasil Belajar Siswa Pada Mata Pelajaran Geografi Di Sma Negeri 1 Marawola. E Journal Geo-Tadulako Untad, 1-13.

Selvi, K. (2010). Motivating Factors In Online Courses. Procedia - Social And Behavioral Sciences, 2(2), 819-824. Https://Doi.Org/10.1016/J.Sbspro.2010.03.110

Siagian, P. S. (2004). Teori Motivasi Dan Aplikasinya. Rineka Cipta.

Slameto. (2010). Belajar Dan Faktor-Faktor Yang Mempengaruhinya. Jakarta: Pt. Raja Grafindo Persada.

Sudjana, N. (2017). Penilaian Hasil Proses Belajar Mengajar. Bandung: Remaja Rosdakarya.

Sunadi, L. (2010). Pengaruh Motivasi Belajar Dan Pemanfaatan Fasilitas Belajar Terhadap Prestasi Belajar Siswa Pada Mata Pelajaran Ekonomi Kelas Xi Ips Di Sma Muhammadiyah 2 Surabaya. Jurnal Pendidikan Ekonomi.

Sutardi, S., \& Sugiharsono, S. (2016). Pengaruh Kompetensi Guru, Motivasi Belajar, Dan Lingkungan Keluarga Terhadap Hasil Belajar Mata Pelajaran Ekonomi. Harmoni Sosial: Jurnal Pendidikan Ips, 3(2), 188-198. Https://Doi.Org/10.21831/Hsjpi.V3i2.8400

Uno, H. B. (2014). Teori Motivasi Dan Pengukurannya. Jakarta: Bumi Aksara.

Utaminingtyas, S., Subaryana, \& Fatimah, S. (2020). Pengaruh Lingkungan Keluarga Dan Minat Belajar Terhadap Hasil Belajar Matematika Peserta Didik Kelas V Sekolah Dasar Tahun Ajaran 2019/2020. 
2122 Lingkungan Keluarga dan Motivasi Belajar terhadap Hasil Belajar Mata Pelajaran Ekonomi pada Pembelajaran Daring - Affan Rais Annauval, Muhammad Abdul Ghofur

DOI: https://doi.org/10.31004/edukatif.v3i5.761

4(1), 114-124.

Wahid, F. S., Setiyoko, D. T., Riono, S. B., \& Saputra, A. A. (2020). Pengaruh Lingkungan Keluarga Dan Lingkungan Sekolah Terhadap Prestasi Belajar Siswa. Syntax Literate; Jurnal Ilmiah Indonesia, 5(8), 555. Https://Doi.Org/10.36418/Syntax-Literate.V5i8.1526

Wahyuni, D. S. (2016). Pengaruh Efikasi Diri, Cara Belajar, Persepsi Siswa Tentang Komunikasi Guru Dan Persepsi Siswa Tentang Perhatian Orangtua Terhadap Hasil Belajar Siswa Kelas Xi Man Di Kota Palu. Matematika Dan Pembelajaranyaatematika Dan Pembelajaranya, 2(1), 105-126. 